\title{
Oral health status among women with oral contraceptives
}

Karama MT Al-Nuaimy BDS, MSc (Assist Lect)
Department of Basic Sciences

College of Dentistry, University of Mosul

\begin{abstract}
The present study was conducted to investigate the safety and efficacy of oral contraceptive drugs on oral health and to determine the prevalence of dental caries, plaque, calculus and gingival indices. The sample comprised of 90 females attended to Family Regulation Unit of Al-Hadbaa Health Center in Mosul during the period from 2003 to 2004. Sixty females using oral contraceptives (for at least three years), which are combinations of oestrogen and progesterone. The other 30 healthy women were acted as control group with similar age groups and a mean age of 31 years.

The oral contraceptive drugs modify oral health. In the present study, the prevalence of dental caries, plaque, calculus and gingival indices increased in all women using oral contraceptive drugs than the prevalence in the women of the control group.

In view of the possible factors that cause increase of the indices, suggested a hormonal factor especially oestrogen and progesterone hormones, which have an effect on rate and pattern of hard and soft tissues resulting in reduced the ability to repair and maintain the oral health status.
\end{abstract}

contraceptive drugs.

$$
\begin{aligned}
& \text { الخلاصة } \\
& \text { أجريت هذه الدراسـة لقياس وتحديد سـلامة وقوة } \\
& \text { تأثير حبوب منع الحمل على صحة الفم، ولقياس شدة التحرة } \\
& \text { دوال التسـوس والقـلاح والتكلس والتهـاب اللثة. شـملت }
\end{aligned}
$$

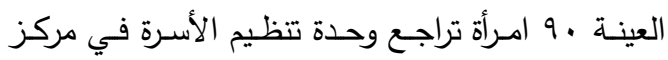

$$
\begin{aligned}
& \text { الحدباء في الموصل خلال الفترة من عام ؟ ... ب لغاية }
\end{aligned}
$$

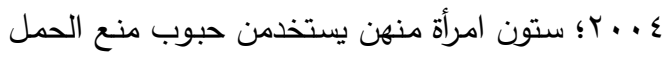

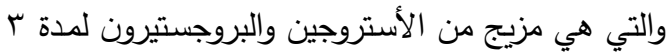

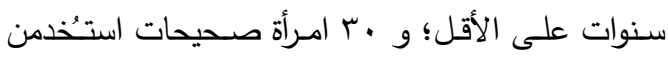

$$
\begin{aligned}
& \text { كمجموعة ضابطة وبنفس العمر بمعدل الب سنة. }
\end{aligned}
$$

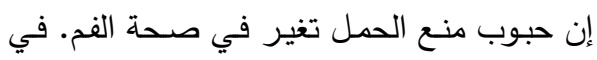

$$
\begin{aligned}
& \text { هذه الدراسة كانت نسبة تسوس الأسنان ودوال الصفيحة } \\
& \text { الجرثومية والقلاح والتهاب اللثة مرتفعة عند كل النساء } \\
& \text { اللواتي يستخدمن حبوب منع الحمل عنها عند المجموعة }
\end{aligned}
$$

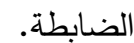

$$
\begin{aligned}
& \text { وفي ظل العوامل التي تسبب هذه الزيـادة في } \\
& \text { الدوال يقترض وجود عامل هورموني بالأخص هورمونا }
\end{aligned}
$$

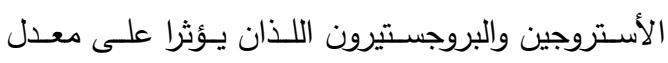

$$
\begin{aligned}
& \text { ونظـام الأنسجة الصلبة والرخوة نتيجـة اختزال القابليـة } \\
& \text { لإعادة واستمرار حالة صحة الفم. }
\end{aligned}
$$

\section{INTRODUCTION}

Oral contraceptives (the pills) have found rapid and wide spread use. It is a family planning; they are synthetic steroids which contain progesterone and oestrogen and are also known as pills. They have to be taken orally for 21 days and discontinued for 5 days to allow menstruation. Increased levels of progesterone inhibit the secretion of luteinizing hormone and prevent ovulation. The oral contraceptives produce hormonal situations similar to pregnancy. ${ }^{(1,2)}$

The oestrogen component gains its contraceptive efficacy by blocking ovulation by inhibiting the release of folliclestimulating hormone and lutenizing hormone, while the progesterone enhance the viscosity of cervical fluid: A change in the endometrial lining that makes it unsuitable 
for egg implantation. ${ }^{(2,3)}$

The endocrine changes are the most significant basic alterations that occurred with oral contraceptives. The production of sex hormones is stimulated by the gonadotropins from the pituitary. The systemic or physical changes that occurred in females taking oral contraceptives include weight gain, restricted respiratory function, postural hypotension, syncope, in addition to stress and change in oral health. ${ }^{(4)}$

The use of oral contraceptives elevates the serum levels of female sex hormones. These hormones have been positively associated with increased gingival crevicular fluid and effect on oral health. ${ }^{(5,6)}$

The aims of this study were to determine the prevalence of dental caries, plaque, calculus and gingivitis in females receiving oral contraceptive drugs and in females that do not receive this drug; to find if there is any relationship between the use of oral contraceptive drug and oral health status; and to provide a baseline in Iraq for further investigations.

MATERIALS AND METHODS
The sample consists of 90 healthy females with no history of any systemic disease; thirty females as a control group and the other 60 females as study group taking the same type of oral contraceptive drugs for 3 years and above, which are combines of oestrogen and progesterone. The dose is usually one tablet daily (taken at approximately the same time each day) for 21 days, followed by a 7-day interval during which menstruation occurs. The age of females was between $30-45$ years; at mean 31 years.

The females have been selected from Family Regulation Unit of Al-Hadbaa Health Center in Mosul.

The questionnaire form prior to the oral examination was filled by the investigator and includes: Name, age, address, date of birth, medical history and duration of oral contraceptive drug use.

For clinical oral examination, the use of a plane mouth mirror and a sharp explorer. The examination was as shown in scheme of procedure:

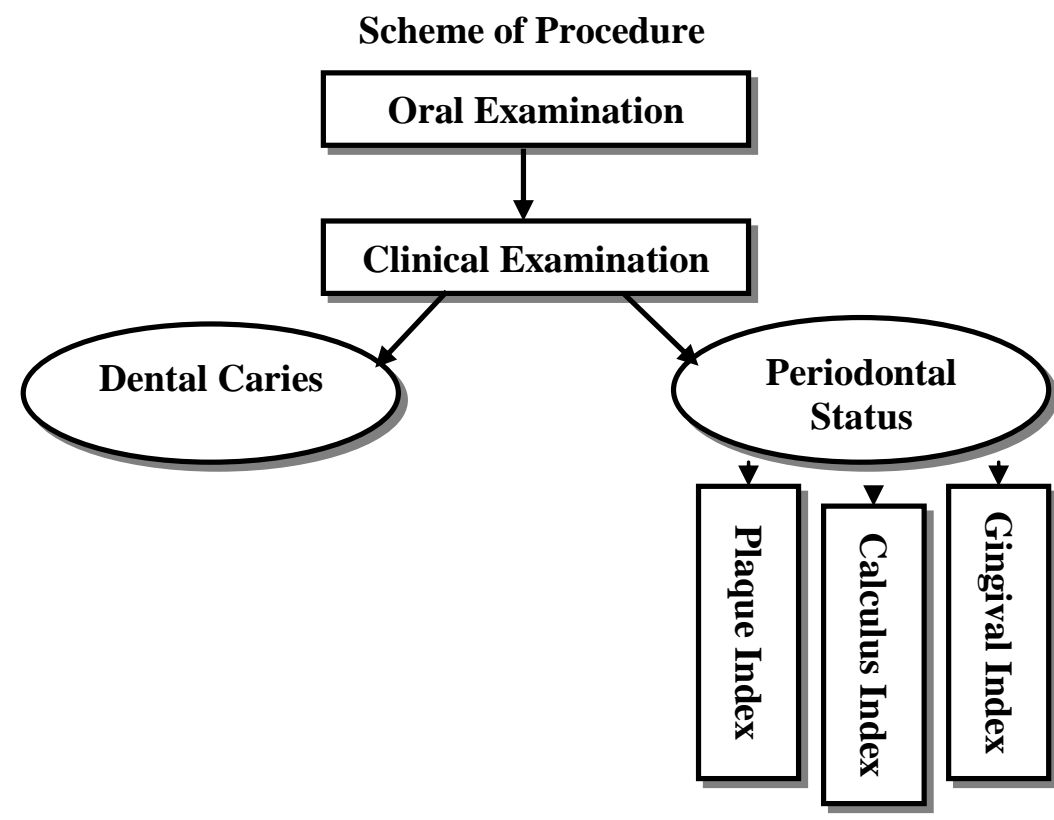

Statistical analyses of data were carried out using mean \pm standard deviation (SD), $p$-value, $\mathrm{t}$-test and coefficient of variability (CV) between females using oral contraceptive drugs and control group.

\section{Dental Caries}

\section{RESULTS}

Table (1) showed that females taking oral contraceptive drugs had higher dental caries index when compared with control group.

\section{Periodontal Status}

1) Plaque Index 
The females taking oral contraceptive drugs had significantly higher mean \pm SD of plaque index than control group as shown in Table (2).

\section{2) Calculus Index}

Table (3) showed that the mean calculus index was found to be signifi- cantly higher in study group than control group.

\section{3) Gingival Index}

The mean \pm SD and $p$-value of gum inflammation was higher in study group than control group as shown in Table (4).

Table (1): Mean \pm SD and CV\% of dental caries of two groups

\begin{tabular}{cccc}
\hline Subject & No. & Mean \pm SD & CV\% \\
\hline With Oral Contraceptive & 60 & $3.20 \pm 1.21$ & 37.81 \\
Without Oral Contraceptive & 30 & $0.82 \pm 0.02$ & 2.43 \\
\hline$p<0.005:$ Highly significant. \\
CV: Coefficient of variability. \\
SD: Standard deviation.
\end{tabular}

Table (2): Mean \pm SD and CV\% of plaque index of two groups

\begin{tabular}{cccc} 
Subject & No. & Mean \pm SD & CV\% \\
\hline With Oral Contraceptive & 60 & $2.92 \pm 0.48$ & 16.43 \\
Without Oral Contraceptive & 30 & $0.54 \pm 0.21$ & 0.38 \\
\hline$p<$ 0.005: Highly significant. \\
CV: Coefficient of variability. \\
SD: Standard deviation.
\end{tabular}

Table (3): Mean \pm SD and CV\% of calculus index of two groups

\begin{tabular}{cccc} 
Subject & No. & Mean \pm SD & CV\% \\
\hline With Oral Contraceptive & 60 & $3.52 \pm 0.32$ & 10.79 \\
Without Oral Contraceptive & 30 & $0.85 \pm 0.32$ & 37.64 \\
\hline$p<0.005:$ Highly significant. \\
CV: Coefficient of variability. \\
SD: Standard deviation.
\end{tabular}

Table (4): Mean \pm SD and CV\% of gingival index of two groups

\begin{tabular}{cccc} 
Subject & No. & Mean \pm SD & CV\% \\
\hline With Oral Contraceptive & 60 & $2.82 \pm 0.48$ & 17.02 \\
Without Oral Contraceptive & 30 & $0.95 \pm 0.46$ & 48.42 \\
\hline$p<0.005:$ Highly significant. \\
CV: Coefficient of variability. \\
SD: Standard deviation.
\end{tabular}

\section{DISCUSSION}

Some problems still exist in this country; i.e., bad oral hygiene. This has been reflected in the presence of a large number of women who use oral contraceptives. Strict comparison of the results of this study with the available studies is somewhat difficult due to the fact that those studies did not define the target group precisely since the women use oral contraceptives is a group of disorders in oral cavity.

Dental Caries

In females, using oral contraceptives 
found increase in dental caries. This is due to endocrine ovarian hormones which alter the microenvironment of oral cavity. ${ }^{(7)}$

Also, due to sample collection from the adult age over 30 years old, the carious teeth increased with age. Also, the females become neglecting their dental health with advanced age and multiple children. ${ }^{(8)}$

\section{Periodontal Status}

The plaque index of Silness and Löe $(1964)^{(9)}$ was used to assess the soft deposit on the gingival area of tooth surface together with the gingival index of Löe and Silness $(1963)^{(10)}$ to assess the gingival condition. These indices were chosen for their world wide acceptance, ease to application and flexibility.

The present study shows that females receiving oral contraceptives had a mean plaque index higher than that found in control group. This is due to possibly multifactorial, including increased plasma female sex hormones, alteration in dental plaque and perhaps prevotella intermedia in the subgingival plaque, plus alteration of the immune response. ${ }^{(11,12)}$

Females taking oral contraceptives in this study had gingival scores higher than those of control group. This difference is due to oestrogen and progesterone hormones are available in their active form in and around oral tissues and structures of females take oral contraceptives. ${ }^{(12-14)}$ Also, it is well established that gingivitis is initiated by bacterial, dental plaque, restoration, dental appliances, certain genetic disorders and hormonal changes, which aggravate the gingival response to local irritants when taken for long periods of time (longer than 1.5 years) which increased periodontal destruction. ${ }^{(15-18)}$

\section{CONCLUSION}

All women using oral contraceptive drugs were presented with different grades of oral health; the data indicated the significant alterations. It is increased in the prevalence of dental caries, plaque, calculus and gingival indices than the prevalence in the women of the control group. Recognition of interrelationship between pharmacological and physiological processes will help practitioners to identify the etiology of these disorders.

\section{REFERENCES}

1. Kalkorf KL. Effect of oral contraceptive therapy on gingival inflammation in hu-mans. $J$ Periodontol. 1978; 49: 560-565.

2. Tandan HC, Chandramouli R. Oral contraceptives. In: Textbook of Physio-logy for Dental Students. $7^{\text {th }}$ ed. Banga-lore Medical Publisher Press. 2002; Pp: 192-198.

3. Hersh EV. Adverse drug interactions in dental practice. J Am Dent Assoc. 1999; 130: 236-251.

4. Lindhe J, Björn AL. Influence of hor-monal contraceptives on the gingiva of women. $J$ Periodont Res. 1967; 2: 1-4.

5. Kuramitsu HK. Virulence properties of oral bacteria. Impact of molecular bio-logy. Curr Iss Mol Biol. 2001; 3(2): 35-36.

6. Hertz RS, Beckstead PC, Brown WJ. Epithelial melanosis of the gingiva poss-ibly resulting from the use of oral cont-raceptives. $J$ Am Dent Assoc. 1988; 100(5): 713-722.

7. Pankhursh CL, Blank DD, Stock BA. The influence of oral contraceptive ther-apy on the periodontium duration of drug therapy. J Periodontol. 1981; 52(10): 612-616.

8. Zachariasen RD. The effect of elevated ovarian hormones on periodontal health women. Obstet Gynecol Clin J. 1993; 20(2): 21-30.

9. Silness J, Löe H. Periodontal disease in pregnancy. Part II. Correlation between oral hygiene and periodontal condition. Acta Odontol Scand. 1964; 22: 121-126.

10. Löe H, Silness J. Periodontal disease in pregnancy. Part I. Prevalence and sever-ity. Acta Odontol Scand. 1963; 21: 533-551.

11. Gonzaga HF, Busol L, Gorge AM, Gon-zaga LA. Intra-uterine dentistry. An int-egrated model of 
prevention. Braz Dent J. 2001; 12(2): 139-142.

12. Mendenhall HW. Effect of oral contra-ceptives on serum protein concentration. Am J Obstet Gynecol. 2000; 139: 720-728.

13. Hugoson A, Kock G, Rylander H. Prevalence and distribution of gingivitis-periodontitis in children and adolescents. Swed Dent J. 1986; 5: 91-103.

14. Sulaiman AWR. Oral health status and cariogenic microflora during pregnancy. MSc thesis. College of Dentistry. Univ-ersity of Baghdad. 1995; Pp: 35-42.

15. Lobene RR. Discussion: Current status of indices for measuring

Received: 30/10/2003 gingivitis. J Clin Periodontol. 1996; 113: 381-392.

16. Knight GM, Wade AB. The effect of hormonal contraceptives on the human periodontium. J Periodont Res. 1984; 9: 18-23.

17. Whitehead N, Royner F, Lindenbaum J. Megaloblastic changes in the cervical epithelium association with oral contra-ceptive therapy and reversal with folic acid. J Am Med Assoc. 1983; 12: 14211427.

18. Philip M, Hoa G, Elizabeth A, Pawlak J. Basic Etiology of Periodontal Disease. In: Essentials of Periodontics. $4^{\text {th }}$ ed. Medical Publisher Press, USA. 1990; Pp: 3036.

Accepted for Publication: 12/6/2004 